OPEN ACCESS

Edited by:

Leigh Breen,

University of Birmingham,

United Kingdom

Reviewed by:

Chris McGlory,

McMaster University, Canada

Brian P. Carson,

University of Limerick, Ireland

${ }^{*}$ Correspondence:

Joseph W. Beals

bealsjw@wustl.edu

Specialty section: This article was submitted to Sport and Exercise Nutrition,

a section of the journal

Frontiers in Nutrition

Received: 09 April 2019

Accepted: 23 May 2019

Published: 13 June 2019

Citation:

Beals JW, Burd NA, Moore DR and van Vliet S (2019) Obesity Alters the

Muscle Protein Synthetic Response to

Nutrition and Exercise.

Front. Nutr. 6:87.

doi: 10.3389/fnut.2019.00087

\section{Obesity Alters the Muscle Protein Synthetic Response to Nutrition and Exercise}

\author{
Joseph W. Beals ${ }^{1 *}$, Nicholas A. Burd ${ }^{2}$, Daniel R. Moore ${ }^{3}$ and Stephan van Vliet ${ }^{4}$ \\ ${ }^{1}$ Center for Human Nutrition, Washington University School of Medicine, St. Louis, MO, United States, ${ }^{2}$ Department of \\ Kinesiology and Community Health, University of Illinois at Urbana-Champaign, Urbana, IL, United States, ${ }^{3}$ Faculty of \\ Kinesiology and Physical Education, University of Toronto, Toronto, ON, Canada, ${ }^{4}$ Duke Molecular Physiology Institute, Duke \\ University Medical Center, Durham, NC, United States
}

Improving the health of skeletal muscle is an important component of obesity treatment. Apart from allowing for physical activity, skeletal muscle tissue is fundamental for the regulation of postprandial macronutrient metabolism, a time period that represents when metabolic derangements are most often observed in adults with obesity. In order for skeletal muscle to retain its capacity for physical activity and macronutrient metabolism, its protein quantity and composition must be maintained through the efficient degradation and resynthesis for proper tissue homeostasis. Life-style behaviors such as increasing physical activity and higher protein diets are front-line treatment strategies to enhance muscle protein remodeling by primarily stimulating protein synthesis rates. However, the muscle of individuals with obesity appears to be resistant to the anabolic action of targeted exercise regimes and protein ingestion when compared to normal-weight adults. This indicates impaired muscle protein remodeling in response to the main anabolic stimuli to human skeletal muscle tissue is contributing to poor muscle health with obesity. Deranged anabolic signaling related to insulin resistance, lipid accumulation, and/or systemic/muscle inflammation are likely at the root of the anabolic resistance of muscle protein synthesis rates with obesity. The purpose of this review is to discuss the impact of protein ingestion and exercise on muscle protein remodeling in people with obesity, and the potential mechanisms underlining anabolic resistance of their muscle.

Keywords: exercise, fat mass, muscle mass, mTORC1, p70S6K, inflammation, TLR4, anabolic resistance

\section{INTRODUCTION}

At present, $39 \%$ of adult Americans are obese (1), which is defined as having a body mass index (BMI) of 30 or higher. Obesity represents a growing societal problem as incidence has increased rapidly since the early 2000s when $30 \%$ of American were obese (2). If current trends continue, it is projected that nearly half of all US adults may be obese by 2030 (3). Obesity is associated with several chronic conditions including cancer, type 2 diabetes, cardiovascular disease, arthritis, liver and kidney disease, sleep apnea, mental illness $(4,5)$, and increased risk of all-cause mortality (6). The annual obesity-related healthcare costs in 2005 were estimated at $\$ 190.2$ billion or nearly $21 \%$ of total medical spending in the US (7). Therefore, effective treatment strategies to prevent, halt, and reverse obesity are imperative to improve public health and reduce the societal (e.g., healthcare and economic) cost of obesity. 
The frontline treatment of obesity is typically multifactorial and is predominantly centered around behavior strategies such as changes in nutrition and/or physical activity to elicit weight loss (8). Weight loss, however, commonly occurs with concomitant reductions in skeletal muscle mass (9), the prevention of which is a focus for several research groups $(10,11)$. These efforts are due to the recognized important contribution of skeletal muscle health to total body health (12).

Besides the obvious role in generating force for movement, skeletal muscle also contributes to health through the use and storage of macronutrients (13). Skeletal muscle is the primary determinant of meal-derived glucose (14) and lipid (15) uptake and utilizes a major portion of meal-derived amino acids (AA) released into systemic circulation to build new functional proteins $(16,17)$. Moreover, changes in the skeletal muscle's contribution to basal and/or postprandial macronutrient metabolism can have profound effects on disease risk (18). For example, impaired insulin sensitivity is a fundamental characteristic of Type 2 diabetes (19). Emerging data have revealed that obesity may also negatively alter muscle protein turnover, or the breaking down and rebuilding of functional proteins, with the myofibrillar proteins being particularly susceptible to anabolic resistance. The purpose of this review is to discuss the mechanisms by which obesity may hamper normal turnover of muscle proteins and ultimately impact muscle health (Figure 1). In addition, we discuss lifestyle strategies to improve the muscle protein synthetic response with obesity.

\section{SKELETAL MUSCLE PROTEIN TURNOVER FOR HEALTHY MUSCLE}

Tissue proteins are maintained through the coordination of rates of synthesis (from free AAs) and breakdown (replenishment of the free amino acid pool) under basal conditions. In skeletal muscle, protein synthesis appears to be more highly responsive to changes in plasma amino acid (AA) availability as compared to protein breakdown (MPB) (20-22). Proteins in skeletal muscle are degraded for a variety of reasons including to remodel the muscle in response to changes in metabolic demands (e.g., larger and stronger vs. more fatigue resistant muscles) (23, 24) or as they become old, damaged and subsequently need replacement (25-27). Moreover, as the body's largest pool of AAs, the muscle provides gluconeogenic precursors to other tissues during an overnight $(28,29)$ or prolonged fast $(30)$. Therefore, the stimulation of muscle protein synthesis rates represents an important physiological process for maintaining the health and function of this tissue.

Regulation of muscle protein synthesis rates is coordinated by several extra- and intracellular signals, many of which are increased in response to nutrition (e.g., insulin and AAs; Figure 2A) and physical activity (e.g., muscle contraction; Figure 2A). Changes in protein phosphorylation and activity is fundamentally catalyzed by protein-protein interactions, the study of which has led to a greater understanding of and appreciation for the dynamic nature of mRNA translation regulation in human muscle (31). For example, mixed meal ingestion with protein and carbohydrate induces a rise in plasma aminoacidemia and insulinemia that directs the dissociation of Ras homolog-enriched in brain (Rheb) from its negative regulator tuberous sclerosis complex 2 (TSC2) in order to facilitate Rheb association with the mechanistic target of rapamycin (mTOR) to form the mTOR complex 1 (mTORC1) $(32,33)$. This complex subsequently moves to the lysosome and translocates toward the sarcolemma, which is more proximal to capillaries, AA transporters (e.g., the large neutral amino acid transporter, LAT1 or SLC7A5), and the ribosomal machinery (33-35). This intracellular positioning would presumably be ideally suited to detect and utilize exogenous nutrients for the postprandial muscle protein synthetic response at the level of mRNA translation. In addition, the kinase activity of mTORC1 is essential for the phosphorylation and activation of several proteins involved in ribosomal assembly (e.g., ribosomal protein S6, rpS6; eukaryotic translation initiation factor 4E-binding protein 1, 4EBP1; eukaryotic initiation factor 2, eIF2) either directly, or through downstream kinases (e.g., ribosomal protein S6 kinase 1, p70S6K1) (36, 37). Indeed, phosphorylation of mTOR and these downstream proteins are commonly used readouts of pathway activation (38-42), though it should be appreciated that changes in protein phosphorylation of these candidate markers do not always reflect their kinase activity (43) nor direct proportional changes in muscle protein synthesis (38) in human muscle. Importantly, these processes are also stimulated by muscle contraction (i.e., resistance exercise) with the peripheral targeting of mTORC1 persisting beyond the acute postprandial period (i.e., $>3 \mathrm{~h}$ ) (34), which likely contributes to the sustained p70S6K1 phosphorylation and myofibrillar (i.e., contractile proteins) protein synthetic response with exercise $(44,45)$. There is also in vitro evidence suggesting that, similar to glucose transport, an inducible pool of amino acid transporters (e.g., SNAT2) may also be recruited to the sarcolemma in response to anabolic stimuli, such as insulin, and contribute to the acute regulation of muscle protein synthesis (46). Thus, given the dynamic nature of anabolic signaling events and nutrient transport, any physical or biochemical changes within the skeletal muscle of people with obesity that interferes with these intracellular processes could ultimately contribute to the dysregulation of muscle protein synthesis.

Protein ingestion and exercise have been shown to be two primary anabolic stimuli to human skeletal muscle; protein ingestion being particularly important as it also provides the necessary substrate (i.e., essential AAs) for synthesizing new proteins. The factors involved in the regulation of muscle protein synthesis rates has been studied under a variety of conditions and different populations. From a protein nutrition perspective, a range of $20-40 \mathrm{~g}$ of high quality protein is required to ingest in a single meal to maximize the muscle protein synthetic response during the postprandial period in adult men $(21,47-50)$. Protein type (isolated vs. whole food), exercise pattern (resistance vs. endurance), BMI, and/or age of an individual may all be important factors that modulate the recommended amount of protein to consume in a meal to augment postprandial muscle protein synthesis rates as discussed elsewhere $(51,52)$. 


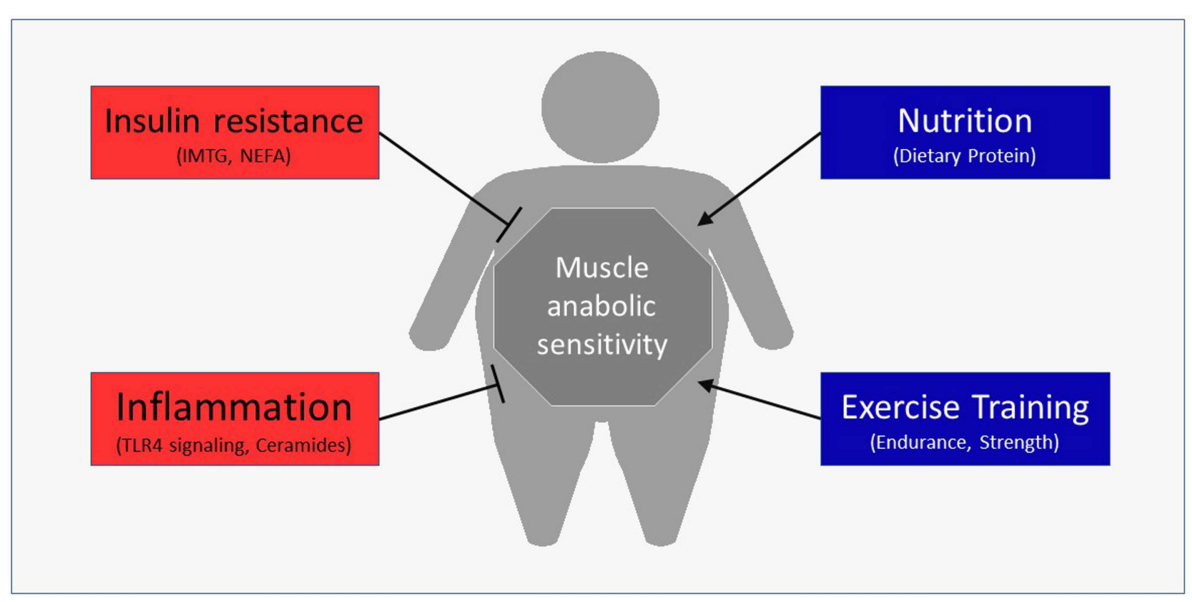

FIGURE 1 | Potential regulators of the postprandial muscle protein synthetic response with obesity.

Muscle protein synthesis, however, is a relatively generic term given the myriad of various structural and regulatory proteins within this tissue. Many studies, however, assess the synthesis of mixed muscle protein, or the entire muscle proteome. In healthy adults, the rates of protein synthesis are not equivalent across sub-fractions of the skeletal muscle $(44,53)$ and mixed muscle protein synthesis represents a weighted average of the rates of these sub-fractions. However, this approach may obscure important phenotypic differences in rates of protein synthesis occurring in specific protein sub-fractions in response to nutrition or exercise. For example, it has been shown that the stimulation of myofibrillar protein synthesis rates is more sensitive to feeding and exercise during early (i.e., $\sim 5 \mathrm{~h}$ ) and later (i.e., $\sim 24 \mathrm{~h}$ ) recovery when compared to the sarcoplasmic protein fraction in healthy adults $(44,54)$. More importantly, muscle subfractional protein synthesis rates are differentially responsive to common stimuli [e.g., insulin, exercise $(38-40,44,55,56)$ ] and may be differentially impacted based on the population studied $(39,40,57)$. Therefore, to obtain a more complete picture of the potential dysregulation of muscle protein metabolism in clinical populations such as the obese it is advantageous to investigate the response in specific sub-fractions.

\section{THE IMPACT OF OBESITY ON MUSCLE PROTEIN TURNOVER}

Basal muscle protein synthesis rates have been assessed in obese individuals in mixed muscle $(41,58)$ and within the myofibrillar (40,42, 59-61), sarcoplasmic (40,42, 61), and mitochondrial $(41,58,62)$ protein sub-fractions and generally show no impairment when compared to healthy-weight counterparts. Though, lower basal mixed muscle (41) and mitochondrial (58) protein synthesis rates in individuals with obesity as compared to non-obese individuals have also been reported. The reasons for these discrepant findings are not clear, and may reflect the heterogeneity observed with obesity, which is discussed later on. However, obesity is characterized by several well-known impairments in macronutrient metabolism in skeletal muscle that results in altered regulation of blood glucose and lipids (63). Accumulating evidence also suggests that stimulation of muscle protein synthesis rates during the postprandial period is altered in obese individuals as compared to normal-weight controls (defined as a body mass index; BMI $\left.<25 \mathrm{~kg} / \mathrm{m}^{2}\right)(40-42,58-$ $60)$, although this finding is not universal $(61,62)$. Moreover, the specific alterations to muscle sub-fractions (e.g., mitochondrial, myofibrillar, and/or sarcoplasmic) are also not consistent among studies. These discrepancies between studies may relate to a lack of standardized participant grouping (e.g., healthy-weight (BMI $\left.<25 \mathrm{~kg} / \mathrm{m}^{2}\right)$ vs. non-obese individuals $\left(\mathrm{BMI}<30 \mathrm{~kg} / \mathrm{m}^{2}\right)$ as controls) and/or postprandial conditions (i.e., meal ingestion vs. AA infusions) among study designs. A summary of the above studies is presented in Table $\mathbf{1}$ and their main findings will be discussed in the next sections.

Much of the earlier work studying the effects of obesity on the regulation of postprandial muscle protein synthesis rates centered on the intravenous delivery of AAs during a clamp procedure. Under hyperinsulinemic-hyperaminoacidemic clamp conditions, it has been reported that obese men exhibit lower rates of mixed muscle (58), myofibrillar (59), mitochondrial (58) protein synthesis when compared to controls, although evidence is also available that do not support these differences $(41,61)$. While a hyperinsulinemic-euglycemic clamp may represent the gold-standard for assessing insulinsensitive glucose disposal, sustained hyperaminoacidemia (with or without hyperinsulinemia) is an atypical stimulus that may be associated with a refractory stimulation of muscle protein synthesis (64). Thus, the physiological relevance of clamp conditions for assessing the impact of protein nutrition on postprandial regulation of muscle protein synthesis is arguably limited.

Relatively few experiments have compared the stimulation of postprandial muscle protein synthesis rates in individuals with obesity vs. healthy-weight individuals under the typical applied setting of ingesting protein-dense foods $(42,60,62)$. These experiments, which have incorporated the ingestion of a bolus of high-quality protein [i.e., milk (60) or lean pork $(42,62)$ ], 


\section{A}

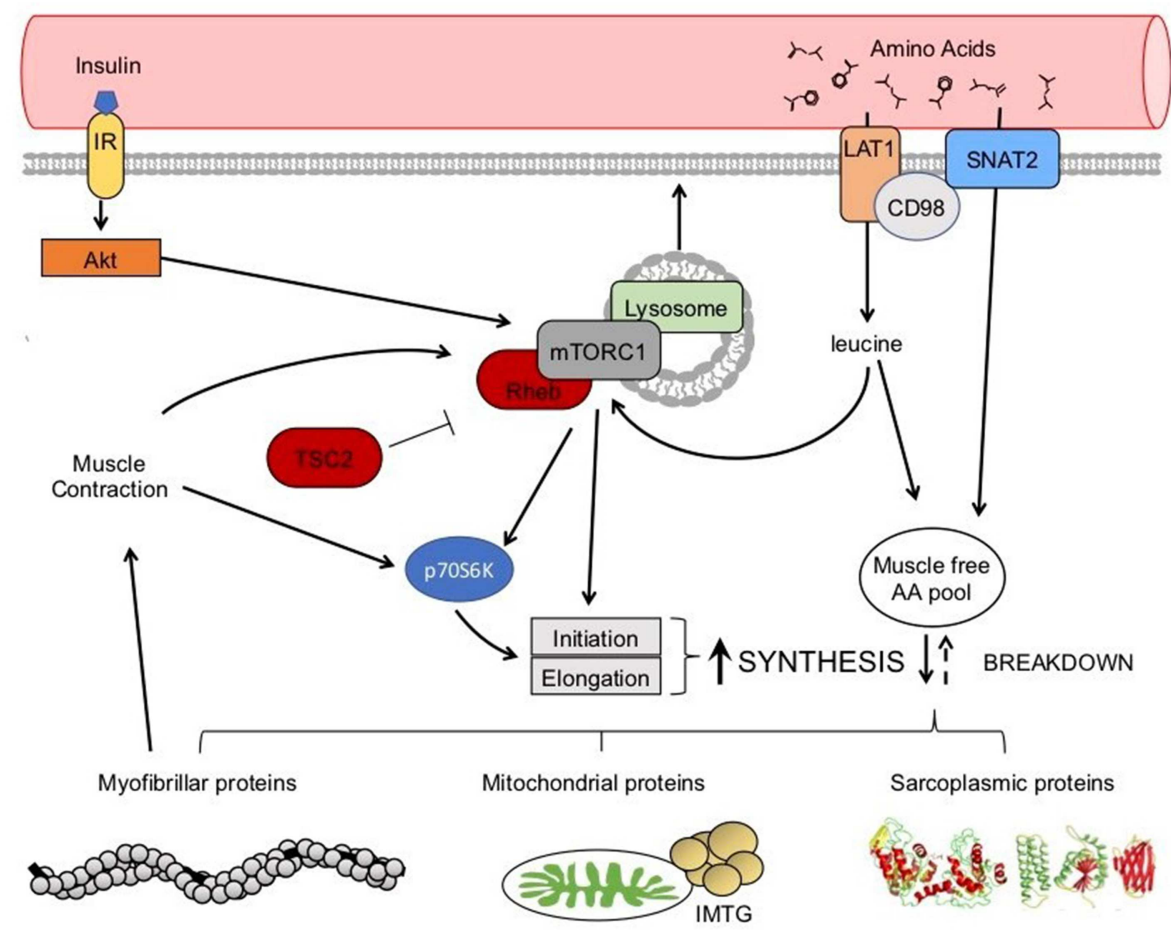

B

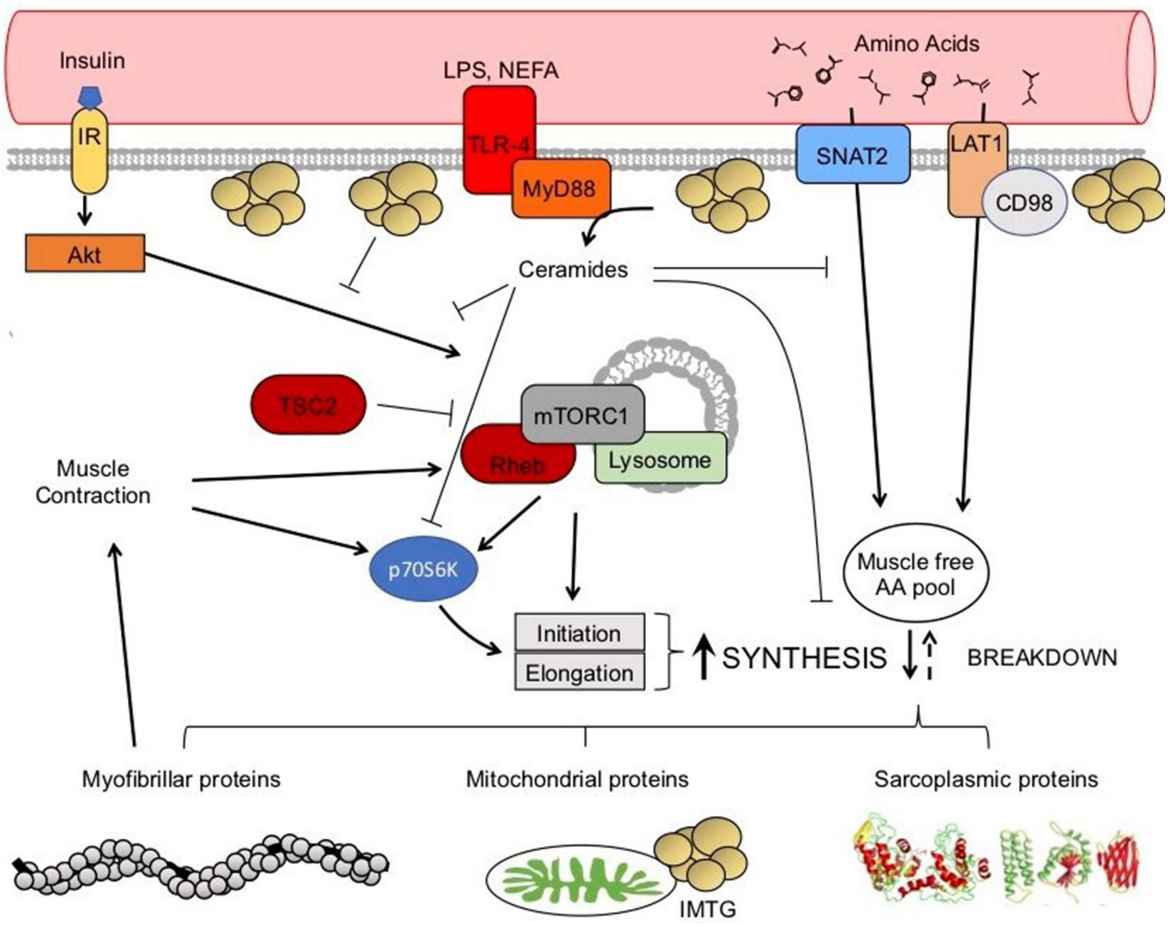

FIGURE 2 | Healthy anabolic signaling in the skeletal muscle (A). Potential dysregulation to anabolic signaling with obesity (B). $\rightarrow$ indicates a stimulation. $\perp$ indicates an inhibition. 
TABLE 1 | Effect of obesity on human muscle protein synthesis.

\begin{tabular}{|c|c|c|c|c|c|c|}
\hline \multicolumn{7}{|c|}{ AMINO ACID INFUSION STUDIES } \\
\hline Experiment & Populations studied & Conditions & & $\begin{array}{l}\text { Basal MPS } \\
\text { OB vs. CON }\end{array}$ & $\begin{array}{l}\text { OB Postprandial } \\
\text { MPS vs. basal }\end{array}$ & $\begin{array}{l}\text { Postprandial MPS } \\
\text { OB vs. CON }\end{array}$ \\
\hline \multirow[t]{2}{*}{ Guillet et al. (58) } & Young men & Hyper-AA & & $\downarrow$ Mixed & $\uparrow$ Mixed & $\downarrow$ Mixed \\
\hline & OB vs. Non-OB (CON) & hyperinsulinemia & & $\downarrow$ Mito & $\leftrightarrow$ Mito & $\downarrow$ Mito \\
\hline \multirow[t]{2}{*}{ Murton et. al. (59) } & Older men & Hyper-AA & & $\leftrightarrow$ Myo & $\leftrightarrow$ Myo & $\downarrow$ Myo \\
\hline & OB vs. HW (CON) & hyperinsulinemia & & & & \\
\hline \multirow[t]{2}{*}{ Chevalier et al. (61) } & Young men & Hyper-AA & & $\leftrightarrow$ Myo & $\uparrow$ Myo & $\leftrightarrow$ Myo \\
\hline & OB vs. HW (CON) & hyperinsulinemia & & $\leftrightarrow$ Sarc & $\uparrow$ Sarc & $\leftrightarrow$ Sarc \\
\hline \multirow[t]{2}{*}{ Tran et al. (41) } & Young men & Hyper-AA & & $\downarrow$ Mixed & $\uparrow$ Mixed & $\leftrightarrow$ Mixed \\
\hline & OB vs. HW (CON) & & & $\downarrow$ Mito & $\uparrow$ Mito & $\leftrightarrow$ Mito \\
\hline \multicolumn{7}{|c|}{ PROTEIN INGESTION STUDIES } \\
\hline Experiment & Populations studied & Protein source & & $\begin{array}{l}\text { Basal MPS } \\
\text { OB vs. CON }\end{array}$ & $\begin{array}{l}\text { OB Postprandial } \\
\text { MPS vs. basal }\end{array}$ & $\begin{array}{l}\text { Postprandial MPS } \\
\text { OB vs. CON }\end{array}$ \\
\hline \multirow[t]{2}{*}{ Beals et al. (42) } & Young adults & Lean pork (36 g) & & $\leftrightarrow$ Myo & $\leftrightarrow$ Myo & $\downarrow$ Myo \\
\hline & OB vs. HW (CON) & & & & & \\
\hline \multirow[t]{2}{*}{ Beals et al. (62) } & Young adults & Lean pork (36 g) & & $\leftrightarrow$ Mito & $\uparrow$ Mito & $\leftrightarrow$ Mito \\
\hline & OB vs. HW (CON) & & & & & \\
\hline \multirow[t]{2}{*}{ Smeuninx et al. (60) } & Older adults & Milk protein isolate & $(15 \mathrm{~g})$ & $\leftrightarrow$ Myo & $\leftrightarrow$ Myo & $\downarrow$ Myo \\
\hline & OB vs. HW (CON) & & & & & \\
\hline \multicolumn{7}{|c|}{ EXERCISE STUDIES } \\
\hline Experiment & Populations studied & Protein source & Exercise bout & $\begin{array}{l}\text { Basal MPS } \\
\text { OB vs. CON }\end{array}$ & $\begin{array}{l}\text { OB Postexercise } \\
\text { MPS vs. rest* }\end{array}$ & $\begin{array}{l}\text { Postexercise MPS } \\
\text { OB vs. CON }\end{array}$ \\
\hline Hulston et al. (72) & $\begin{array}{l}\text { Young adults } \\
\text { OB vs. HW (CON) }\end{array}$ & $\mathrm{N} / \mathrm{A}$ & $\begin{array}{l}\text { Unilateral knee } \\
\text { extension } 4 \text { sets } \\
\text { at } 70 \% 1 \mathrm{RM}\end{array}$ & $\mathrm{N} / \mathrm{A}$ & $\uparrow$ Mixed & $\leftrightarrow$ Mixed \\
\hline Beals et al. (40) & $\begin{array}{l}\text { Young adults } \\
\text { OB vs. HW (CON) }\end{array}$ & Lean pork (36 g) & $\begin{array}{l}\text { Unilateral knee } \\
\text { extension } 4 \text { sets } \\
\text { at } 65-70 \% 1 \mathrm{RM}\end{array}$ & $\begin{array}{l}\leftrightarrow \text { Myo } \\
\leftrightarrow \text { Sarc }\end{array}$ & $\begin{array}{l}\leftrightarrow \text { Myo } \\
\leftrightarrow \text { Sarc }\end{array}$ & $\begin{array}{l}\downarrow \text { Myo } \\
\leftrightarrow \text { Sarc }\end{array}$ \\
\hline
\end{tabular}

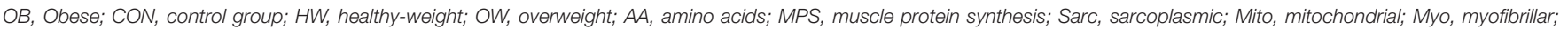
Mixed, mixed muscle; $\leftrightarrow$, no change/difference; $\uparrow$, increased/greater; $\downarrow$, decreased/lower. *these studies used a unilateral model-rest leg was used for this comparison.

have revealed that myofibrillar $(42,60)$, but not mitochondrial protein synthesis rates (62), are reduced in people with obesity compared with healthy-weight individuals after the consumption of protein-dense foods. Indeed, protein-dense food ingestion results in a differential pattern of plasma amino acid availability when compared to directly infusing free AAs intravenously. For example, the ingestion of meat, milk and eggs, important sources of protein in many diet patterns, results in peak plasma amino acid availability occurring $\sim 2 \mathrm{~h}$ after the meal, which wanes over the latter portion of a postprandial period $(65,66)$. The same pattern is also witnessed when observing plasma insulin concentrations after protein ingestion in healthy adults (67). By contrast, clamp conditions are on the other end of the continuum and attempt to alter concentrations of AA and/or insulin in a square wave fashion to maintain concentrations at postprandial or supraphysiological levels over an extended period of time, which may have unintended consequences on muscle protein synthesis rates (64). Clamp conditions also bypass the digestive tract, which plays several important roles in stimulating uptake of nutrients from a meal into peripheral tissues (68-70). Collectively, it is clear that the prime anabolic signals (dietary AAs) to muscle behave very differently when provided as a bolus vs. delivered intravenously, and underlines the value of using more practical approaches when characterizing the impact of nutrition on the regulation of muscle protein synthesis rates in a fraction specific manner with health and disease.

\section{OBESITY-RELATED ANABOLIC RESISTANCE OF MUSCLE PROTEIN SYNTHESIS}

Potential factors underpinning anabolic resistance of muscle protein synthesis with obesity are shown in Figure 2B. Somewhat contradictory to the above data regarding muscle protein synthesis rates, basal phosphorylation of anabolic signaling proteins such as $\mathrm{mTOR}^{\mathrm{S2448}}$ (40-42), and its downstream target ribosomal protein S6 kinase $\left(\mathrm{p} 70 \mathrm{~S} 6 \mathrm{~K}^{\mathrm{T} 389}\right)(40,71)$, are often quite elevated in people with obesity when compared to normalweight individuals. These findings are suggestive of greater basal anabolic signaling in the muscle. However, an elevated phosphorylated-state of basal anabolic signaling mechanisms in people with obesity are not universal findings $(59,72)$, which again serves to reflect the heterogeneity in this condition. Total 
muscle mTOR protein content is also not always reported (41, 72 ), and presenting only ratios of phosphorylated: total protein can mask the true levels of phosphorylated mTOR as several studies have reported greater muscle mTOR protein content in individuals with obesity $(40,42)$. It is currently not fully understood how basal anabolic signals are maintained at these greater levels with obesity. Nevertheless, greater basal mTOR phosphorylation may prevent the characteristic postprandial increase in mTOR phosphorylation in those with obesity $(41,42)$, perhaps suggesting an upper limit for activation of anabolic signaling through this protein complex. For example, one study showing apparently normal basal mTOR phosphorylation in those with obesity, did show increased phosphorylation of mTOR during the postprandial period (59). Phosphorylation of other target proteins downstream of mTORC1 and/or p70S6K signaling [ribosomal protein S6, $\mathrm{rpS}^{\text {S240/244 }}(58,90)$; eukaryotic translation initiation factor $4 \mathrm{E}$-binding protein $1,4 \mathrm{EBP} 1^{\mathrm{T} 37 / 46}$ (58); eukaryotic initiation factor 2, eIF2 ${ }^{\text {S251 }}$ (44)] are unaltered by obesity indicating that proximal aspects of the anabolic signaling pathway are more disrupted compared to healthyweight individuals.

\section{INSULIN RESISTANCE AND MUSCLE ANABOLISM}

Resistance to insulin was historically uncommon in the literature, initially only represented by case studies (73). However, by the 1950s it was recognized that a subset of people with type 2 diabetes were less responsive to insulin and this was accompanied with being overweight or obese (74). Given insulin's role in mTORC1 signaling, diminished responsiveness could be an important aspect of muscle protein metabolism during the postprandial period.

Obesity is often associated with elevated basal plasma circulating branched chain AAs (BCAA) levels (75, 76), which may relate to metabolic changes observed in the skeletal muscle of people with obesity (77). Greater plasma BCAAs concentrations are potentially linked to dysregulation of metabolism with obesity, mostly as it relates to insulin resistance $(75,78-81)$ and chronic activation of the mTORC1 signaling pathway $(82,83)$. These findings could be relevant to observations of elevated basal mTORC1 signaling in people with obesity (40-42). However, only one study that reported the effects of obesity on the mTORC1 signaling pathway and muscle protein synthesis has shown mild elevations $(\sim 20 \%)$ in plasma BCAAs in obese vs. lean individuals (61) with the majority reporting no differences $(40-42,58,60,84)$. Collectively this seems to suggest that elevated basal circulating BCAAs may not be significant nor consistent contributors to the dysregulated muscle protein anabolic response in obesity.

Obesity is also associated with elevated plasma non-esterified fatty acids (NEFA) (85). In fact, infusions of lipid with heparin, which increases plasma NEFAs, can blunt insulin sensitivity even in healthy, insulin-sensitive subjects (86). Lipid infusions also impair myofibrillar protein synthesis in healthy participants under hyperinsulinemic-hyperaminoacidemic conditions (87), which suggests a possible role for insulin resistance in the regulation of myofibrillar protein synthesis. A series of experiments examined the relationship between plasma NEFA concentrations and muscle protein synthesis rates in response to protein ingestion in obese participants and healthy-weight controls $(42,62)$. The participants with obesity in these studies had only subtle differences in postprandial plasma NEFAs, which did not appear to be related to either myofibrillar (42) or mitochondrial protein synthesis (62). In contrast, other have shown that greater intramyocellular lipids are associated with diminished postprandial myofibrillar protein synthesis in obese older adults (60). High intramyocellular lipid is classically associated with insulin resistance in sedentary populations (88), although the causality and mechanistic link for this relationship is not clear. It is worthwhile noting that intramyocellular lipid accumulation in obese human muscle (60) tends to be sub-sarcolemmal as compared to intermyofibrillar in athletic populations (89), which could impair mTORC1 translocation and subsequent downstream activity of this pathway. Alternatively, dysregulated insulin signaling is also attributed to changes in intracellular lipid metabolites (90-92) and in particular the sphingolipid ceramide $(92,93)$. An in vitro study showed that ceramide treatment reduced small neutral amino acid transporter (SNAT2)-mediated sarcolemmal translocation and amino acid transport in L6 myotubes, which translated in an attenuated phosphorylation of p70S6 $\mathrm{K}^{\mathrm{T} 389}$ and amino acid induced stimulation of muscle protein synthesis (94). Thus, the relationship between intramyocellular lipid accumulation and/or ceramide production and the intracellular anabolic signaling (e.g., mTORC1) represents a fruitful area for further study.

Efficient delivery of AAs to peripheral tissues is important for the postprandial stimulation of muscle protein synthesis and may be mediated by an insulin-induced vasodilation of the capillary bed $(95,96)$. Muscle capillarity has been suggested to independently influence peripheral insulin sensitivity and postprandial myofibrillar protein synthesis rates in older adults (97-99), which could implicate a diminished muscle capillary network (100) and/or insulin-induced recruitment (101) in obese individuals as a contributing factor to the anabolic resistance of this population.

Thus, far the impact of obesity per se compared to its associated insulin resistance on the dysregulation of postprandial anabolic response is unknown. For instance, overweight young adults with apparently normal insulinemia and homeostatic model assessment of insulin resistance (HOMA-IR) have also been reported to have a blunted myofibrillar protein synthesis response to protein ingestion and greater basal mTOR phosphorylation (42). This could suggest that increased basal mTOR phosphorylation may occur early with weight gain prior to the development of discernible insulin resistance but concomitant with a blunted postprandial anabolic response. Indeed, substantial evidence has mounted that some individuals with obesity remain nearly as insulin sensitive as lean counterparts while other individuals with a similar degree of obesity become insulin resistant (102). Whether differences in insulin sensitivity are predictive of muscle anabolic sensitivity in obese individuals is currently not known. 


\section{INFLAMMATION AND MUSCLE PROTEIN SYNTHESIS}

Obesity is associated with chronic low-grade inflammation (103), which has been linked to impaired glucose tolerance (104) and dyslipidemia (105). This includes elevated basal levels of plasma inflammatory biomarkers [i.e., CRP $(42,59,60,62,72)$, IL-6 $(42,59,62)$, TNF $\alpha(59)]$ in obese participants. Because of shared metabolic signaling pathways, skeletal muscle inflammation may also contribute to impaired protein anabolism in obese individuals [Figure 2B (106)]. Indeed, protein metabolism is dramatically altered by high levels of inflammation with trauma or severe illness [e.g., thermal injury (107) or end stage renal disease (108)], which may be related to direct effects of some inflammatory markers (e.g., CRP and TNF $\alpha$ ) on suppressing muscle protein synthesis as demonstrated in vitro $(109,110)$.

A few studies have attempted to describe the muscle protein synthetic response to protein ingestion in humans with lowgrade inflammation independent of obesity $(111,112)$. In healthy older men stratified by plasma C-reactive protein (CRP) concentrations, postprandial mixed muscle protein synthetic rates were not different between groups (111). Another group tested the effect of 1 week of ibuprofen or placebo administration on basal and postprandial myofibrillar protein responses to whey protein ingestion in older men with elevated CRP and compared these responses to those of healthy non-inflamed older men (112). In this study, basal and postprandial myofibrillar protein synthesis were not different between ibuprofen and placebo groups. Moreover, both intervention groups (ibuprofen and placebo) had similar basal and postprandial rates of myofibrillar protein synthesis compared with the non-inflamed control group (112). Despite the implication of CRP in attenuating muscle protein anabolism in vitro (109), results in humans, and especially obese individuals, are less clear. Nevertheless, elevated basal levels of plasma inflammatory biomarkers in individuals with obesity [i.e., CRP $(42,59,60,62,72)$, IL-6 $(42,59,62), \mathrm{TNF} \alpha(59)]$ are associated with basal muscle protein synthesis rates that are indistinguishable from healthy-weight non-inflamed controls, but blunted postprandial myofibrillar protein synthesis rates $(42,59,60,62)$, suggesting the impact of low-grade inflammation (e.g., elevated inflammatory cytokines) may depend on the nutrient environment. Moreover, as discussed above, the muscles of overweight individuals are also anabolic resistant (42), but this group does not show indications of systemic or muscle inflammation (62).

Data concerning the effect of muscle inflammation on postprandial muscle protein synthesis in people with obesity is largely limited to the toll-like receptor 4 (TLR4) signaling pathway. This receptor is involved in innate immunity and is primarily known for responding to endotoxin (113), but is also responsive to NEFA (114) and CRP (115) in circulation. TLR4 signaling involves docking with several intracellular proteins, among these is myeloid differentiation factor 88 (MyD88), which appears to potentiate the intracellular signaling of TLR4induced insulin resistance $(114,116)$. Muscle TLR4 protein content correlates with body fat percentage in older adults (117) and is related to NEFA-induced insulin resistance (114).
Although, one group found that muscle content of both TLR4 and MyD88 proteins are greater in obese, anabolic resistant adults compared with healthy-weight controls (62), discerning the impact of obesity or low-grade inflammation on differences in the postprandial muscle protein synthetic response is not possible from the experiment described above.

\section{EXERCISE TO IMPROVE ANABOLIC SENSITIVITY WITH OBESITY}

Leisure time physical activity is a potent treatment for health and its regular performance reduces mortality (118). Physical inactivity has been linked to numerous adverse health outcomes and is predictive of metabolic health with obesity (119). Physical inactivity has also been linked to anabolic resistance in obese older adults (60) and may contribute to the development of sarcopenic obesity (120). For interventions, exercise represents a structured manner to increase daily physical activity. Exercise training takes many forms, but most can be categorized as either endurance (aerobic) or resistance (strength) exercise, though those lines can be somewhat blurred (e.g., high intensity interval training). Each of these training modalities has differing effects on the muscle phenotype, but the effects on muscle tissue health (e.g., insulin sensitivity, endothelial function) appear to be more universal (121-124). Moreover, as physical activity is an essential component of strategies to improve body composition $(125,126)$, it is important to consider how the muscle adaptive response is affected by obesity.

Endurance training is commonly recommended to improve health and body composition in individuals with obesity. There is limited data studying the impact of endurance exercise on the muscle protein synthesis rates in individuals with obesity. However, in healthy, but untrained young men, an acute bout of endurance exercise appears to favor the stimulation of mitochondrial, over myofibrillar, muscle protein synthesis rates during the postprandial period, an effect which was not modified by a 10 -wk training period (39). The same work also reported that resistance exercise tends to increase myofibrillar muscle protein synthesis, in particular after a period of training (39). These findings may be important for determining exercise prescription in those with obesity, given that myofibrillar protein synthesis seems to more affected by obesity $(40,42,59-61)$ than muscle mitochondrial protein synthesis $(41,58,62)$.

A single bout of resistance exercise can induce substantial alterations of macronutrient metabolism such as improvements in glucose tolerance (121) and postprandial lipemia (127) in healthy young men. Resistance exercise also potentiates muscle protein synthesis rates compared with feeding alone in healthyweight young and older men (128), an effect that may persist for up to 2 days $(54,129)$. It appears that resistance exercise is particularly effective at enhancing the myofibrillar (more so than the sarcoplasmic or mitochondrial) sub-fractional protein synthetic response to protein ingestion in healthy adults $(40,44$, 56). Therefore, resistance exercise would ostensibly be an ideal intervention for improving the obesity-related impairment in postprandial myofibrillar protein synthesis rates. 
Two studies have assessed the impact of acute resistance exercise on muscle protein synthesis and related anabolic signaling mechanism in people with obesity, the findings of which are summarized in Tables 1, 2 (40, 72). One investigation observed acute resistance exercise increased mixed muscle protein synthesis in the fasted state with no differences in protein synthetic rates nor anabolic signaling molecule phosphorylation (e.g., mTORC1) between obese and healthyweight adults (72). However, mixed muscle protein synthetic responses represent an average of all muscle proteins, which can have markedly different rates of turnover and contraction and nutrient sensitivities $(44,130,131)$. When sub-fractional protein synthetic responses to resistance exercise after protein ingestion are compared, the postprandial myofibrillar protein synthetic response was not further stimulated by resistance exercise in obese vs. healthy-weight groups whereas sarcoplasmic muscle protein synthesis rates were largely unaffected by obesity or exercise (40). We also reported that resistance exercise prior to protein ingestion did not augment phosphorylation of targets downstream of mTORC1 $\left(\mathrm{p} 70 \mathrm{~S} 6 \mathrm{~K}^{\mathrm{T} 389}, 4 \mathrm{EBP} 1^{\mathrm{T} 37 / 46}\right)$ in those with obesity, which contrasted starkly with their healthy-weight counterparts. As highlighted previously, lysosomal targeting of mTORC1, which appears to be mediated by the production of phosphatidic acid (PA) (132-134), is integral to maximize post-exercise myofibrillar synthetic rates in the fed state (135). Interestingly, ceramide has also been reported to blunt PA production in L6 myoblasts (136), which may have contributed to the attenuated myofibrillar protein synthetic response to resistance exercise in obese individuals (40). Nevertheless, these studies collectively underscore the importance of assessing the

TABLE 2 | Effect of obesity on muscle anabolic signaling.

\begin{tabular}{|c|c|c|c|c|c|c|}
\hline \multicolumn{7}{|c|}{ AMINO ACID INFUSION STUDIES } \\
\hline Experiment & Populations studied & \multicolumn{2}{|l|}{ Conditions } & $\begin{array}{l}\text { Basal OB vs. } \\
\text { CON }\end{array}$ & $\begin{array}{l}\text { OB Postprandial } \\
\text { vs. basal }\end{array}$ & $\begin{array}{l}\text { Postprandial } \\
\text { OB vs. CON }\end{array}$ \\
\hline \multirow[t]{2}{*}{ Murton et al. (59) } & Older men & \multicolumn{2}{|l|}{ Hyper-AA } & $\leftrightarrow \mathrm{mTOR}^{\mathrm{S} 2448}$ & $\uparrow \mathrm{mTOR}^{\mathrm{S} 2448}$ & $\leftrightarrow \mathrm{mTOR}^{\mathrm{S} 2448}$ \\
\hline & OB vs. HW(CON) & \multicolumn{2}{|l|}{ hyperinsulinemia } & & & \\
\hline \multirow[t]{3}{*}{ Chevalier et al. (61) } & Young men & \multicolumn{2}{|l|}{ Hyper-AA } & $\leftrightarrow$ p70S6K $\mathrm{K}^{\mathrm{T} 389}$ & $\uparrow \mathrm{p} 70 \mathrm{~S} 6 \mathrm{~K}^{\mathrm{T} 389}$ & $\downarrow$ p70S6K ${ }^{\top 389}$ \\
\hline & OB vs. HW (CON) & \multicolumn{2}{|l|}{ hyperinsulinemia } & $\leftrightarrow \mathrm{rpS6}^{\mathrm{S} 240 / 244}$ & $\uparrow \mathrm{rpS6}^{\mathrm{S} 240 / 244}$ & $\leftrightarrow \mathrm{rpS6}^{\mathrm{S} 240 / 244}$ \\
\hline & & & & $\leftrightarrow 4 \mathrm{EBP} 1 \mathrm{~S} 65$ & $\uparrow 4 \mathrm{EBP} 1 \mathrm{~S} 65$ & $\leftrightarrow 4 \mathrm{EBP} 1 \mathrm{~S} 65$ \\
\hline \multirow[t]{3}{*}{ Tran et al. (41) } & Young men & \multicolumn{2}{|l|}{ Hyper-AA } & $\uparrow \mathrm{mTOR}^{\mathrm{S} 2448}$ & $\leftrightarrow \mathrm{mTOR}^{\mathrm{S} 2448}$ & $\uparrow \mathrm{mTOR}^{\mathrm{S} 2448}$ \\
\hline & OB vs. HW (CON) & & & $\leftrightarrow$ p70S6K $\mathrm{K}^{\mathrm{T} 389}$ & $\uparrow \mathrm{p} 70 \mathrm{~S} 6 \mathrm{~K}^{\mathrm{T} 389}$ & $\uparrow$ p70S6K ${ }^{\top 389}$ \\
\hline & & & & $\leftrightarrow \mathrm{elF}^{\mathrm{S} 51}$ & $\leftrightarrow \mathrm{elF}^{\mathrm{S} 51}$ & $\leftrightarrow \mathrm{elF}^{\mathrm{S} 51}$ \\
\hline \multirow[t]{3}{*}{ Williamson et al. (71) } & OB,T2D vs. HW (CON) & \multicolumn{2}{|l|}{ Hyperinsulinemia } & $\leftrightarrow$ REDD1 & $\leftrightarrow$ REDD1 & $\uparrow$ REDD1 \\
\hline & & & & 个 p70S6K $\mathrm{K}^{\mathrm{T389}}$ & $\downarrow$ p70S6K $K^{\top 389}$ & $\leftrightarrow$ p70S6K $\mathrm{K}^{\mathrm{T} 389}$ \\
\hline & & & & $\downarrow 4 \mathrm{EBP} 1{ }^{\mathrm{T} 37 / 46}$ & $\leftrightarrow 4 \mathrm{EBP} 1^{\mathrm{T} 37 / 46}$ & $\downarrow 4 \mathrm{EBP} 1^{\mathrm{T} 37 / 46}$ \\
\hline \multicolumn{7}{|c|}{ PROTEIN INGESTION STUDIES } \\
\hline Experiment & Populations studied & \multicolumn{2}{|l|}{ Protein source } & $\begin{array}{l}\text { Basal } \\
\text { OB vs. CON }\end{array}$ & $\begin{array}{l}\text { OB Postprandial } \\
\text { vs. basal }\end{array}$ & $\begin{array}{l}\text { Postprandial } \\
\text { OB vs. CON }\end{array}$ \\
\hline \multirow[t]{2}{*}{ Beals et al. (42) } & Young adults & \multicolumn{2}{|l|}{ Lean pork (36 g) } & $\uparrow \mathrm{mTOR}^{\mathrm{S} 2448}$ & $\leftrightarrow \mathrm{mTOR}^{\mathrm{S} 2448}$ & $\leftrightarrow \mathrm{mTOR}^{\mathrm{S} 2448}$ \\
\hline & OB, OW vs. HW (CON) & & & $\leftrightarrow$ p70S6K $\mathrm{K}^{\mathrm{T} 389}$ & $\uparrow \mathrm{p} 70 \mathrm{~S} 6 \mathrm{~K}^{\mathrm{T} 389}$ & $\uparrow$ p70S6K $\mathrm{K}^{\mathrm{T} 389}$ \\
\hline \multirow[t]{6}{*}{ Gran et al. (84) } & Middle-aged men & \multicolumn{2}{|l|}{ Dairy protein (31 g) } & $\mathrm{N} / \mathrm{A}$ & $\uparrow \mathrm{mTOR}^{\mathrm{S} 2448}$ & $\leftrightarrow \mathrm{mTOR}^{\mathrm{S} 2448}$ \\
\hline & \multirow{2}{*}{\multicolumn{3}{|c|}{ OB w/MetS vs. Non-OB (CON) }} & & $\leftrightarrow$ p70S6K $\mathrm{K}^{\mathrm{T} 389}$ & $\downarrow$ p70S6K $\mathrm{K}^{\mathrm{T} 389}$ \\
\hline & & & & & $\uparrow \mathrm{rpS6}^{\mathrm{S} 240 / 244}$ & $\leftrightarrow \mathrm{rpS6}^{\mathrm{S} 240 / 244}$ \\
\hline & & \multicolumn{2}{|l|}{ Soy protein (31 g) } & $\mathrm{N} / \mathrm{A}$ & $\leftrightarrow \mathrm{mTOR}^{\mathrm{S} 2448}$ & $\leftrightarrow \mathrm{mTOR}^{\mathrm{S} 2448}$ \\
\hline & & & & & $\leftrightarrow{\mathrm{p} 70 S 6 \mathrm{~K}^{\mathrm{T} 389}}$ & $\downarrow p 70 S 6 K^{T 389}$ \\
\hline & & & & & $\leftrightarrow \mathrm{rpS6}^{\mathrm{S} 240 / 244}$ & $\leftrightarrow \mathrm{rpS} 6^{\mathrm{S} 240 / 244}$ \\
\hline \multicolumn{7}{|l|}{ EXERCISE STUDIES } \\
\hline \multirow[t]{2}{*}{ Experiment } & Populations studied & Protein source & Exercise bout & Basal & OB Postexercise & Postexercise \\
\hline & & & & OB vs. CON & vs. rest ${ }^{\star}$ & OB vs. CON \\
\hline \multirow[t]{3}{*}{ Hulston et al. (72) } & Young adults & N/A & Unilateral knee & $\leftrightarrow \mathrm{mTOR}^{\mathrm{S} 2448}$ & $\uparrow \mathrm{mTOR}^{\mathrm{S} 2448}$ & $\leftrightarrow \mathrm{mTOR}^{\mathrm{S} 2448}$ \\
\hline & OB vs. HW (CON) & & extension 4 & $\leftrightarrow$ p70S6K ${ }^{\top 389}$ & $\uparrow p 70 S 6 K^{\top 389}$ & $\leftrightarrow$ p70S6K ${ }^{\mathrm{T} 389}$ \\
\hline & & & sets at $70 \% 1 \mathrm{RM}$ & $\leftrightarrow 4 \mathrm{EBP} 1{ }^{\mathrm{T} 37 / 46}$ & $\uparrow 4 \mathrm{EBP} 1^{\mathrm{T} 37 / 46}$ & $\leftrightarrow 4 \mathrm{EBP} 1{ }^{\mathrm{T} 37 / 46}$ \\
\hline \multirow[t]{3}{*}{ Beals et al. (40) } & Young adults & \multirow[t]{3}{*}{ Lean pork (36 g) } & Unilateral knee & $\uparrow \mathrm{mTOR}^{\mathrm{S} 2448}$ & $\leftrightarrow \mathrm{mTOR}^{\mathrm{S} 2448}$ & $\leftrightarrow \mathrm{mTOR}^{\mathrm{S} 2448}$ \\
\hline & OB vs. HW (CON) & & extension 4 sets & $\uparrow \mathrm{p} 70 \mathrm{~S} 6 \mathrm{~K}^{\mathrm{T} 389}$ & $\leftrightarrow$ p70S6K $\mathrm{K}^{\mathrm{T} 389}$ & $\downarrow$ p70S6K ${ }^{T 389}$ \\
\hline & & & at $65-70 \% 1 \mathrm{RM}$ & $\leftrightarrow 4 \mathrm{EBP} 1 \mathrm{~T}^{\mathrm{T}} 7 / 46$ & $\leftrightarrow 4 \mathrm{EBP} 1{ }^{\mathrm{T} 37 / 46}$ & $\downarrow 4 \mathrm{EBP} 1{ }^{\mathrm{T} 37 / 46}$ \\
\hline
\end{tabular}

OB, obese; CON, control group; HW, healthy-weight; OW, overweight; AA, amino acids; mTORC1, mechanistic target of rapamycin; p70S6K, ribosomal protein S6 kinase; rpS6,

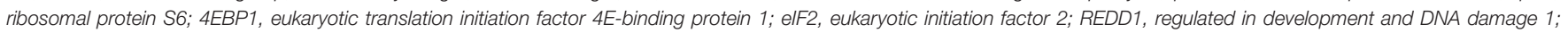

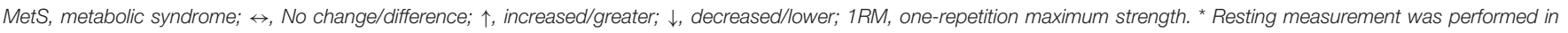
contralateral non-exercised leg. 
sub-fractional protein synthetic responses to the independent and combined anabolic effect of resistance exercise and protein ingestion.

Combined endurance and resistance (i.e., concurrent) exercise training has been demonstrated to have beneficial effects on body composition in adults with overweight or obesity (137). An acute bout of concurrent exercise has been demonstrated to alleviate the suppressive effect of elevated NEFAs on postprandial mixed muscle protein synthesis rates in middle-aged men with overweight or obesity (138). There are relatively few studies that employed a longitudinal design incorporating a combined endurance and resistance exercise approach in obese older adults (139-141). These studies reported rates of mixed muscle protein synthesis before, during, and after exercise with somewhat equivocal results. Two reports showed that increased multimodality physical activity (endurance + resistance) over a 3 month period increases basal mixed muscle protein synthesis rates, but the magnitude of postprandial stimulation of muscle protein synthesis rates was not affected (140). In contrast, the same group also reported, in a similar population, that weight loss over 12 months of caloric restriction with multi-modality physical activity does not change either basal or postprandial mixed muscle protein synthesis rates (141). That study did show that during active weight loss, measured at 3 months of the intervention, the postprandial mixed muscle protein synthesis rates were substantially elevated. The latter finding indicates that prolonged energy restriction with relatively low protein intake $(1.0 \mathrm{~g} / \mathrm{kg} /$ day $)$ may hamper the muscle anabolic response to multi-modality exercise (141).

Several studies have shown that greater dietary protein $(>1.2$ $\mathrm{g} / \mathrm{kg} /$ day) helps to preserve muscle protein synthesis rates during caloric restriction-induced weight loss ( $\sim 40 \%$ energy restriction) in healthy-weight (142) and individuals with overweight or obesity $(10,143)$. In overweight and obese men, the amount of dietary protein required to sustain muscle protein synthesis rates during caloric restriction could be even greater when a high volume of exercise (resistance training and high-intensity intervals) is also performed (143). These studies (10, 141, 143) serve to underscore the importance of considering both nutrition and physical activity when designing interventions to treat obesity and/or its co-morbidities.

\section{CONCLUSIONS}

Protein ingestion is an important component of a healthy diet and has been touted for its potential to facilitate weight loss for those with obesity (144). When studies are considered together, obesity primarily affects the postprandial myofibrillar protein synthetic response to nutrition and exercise (Table 1), which is likely related to altered intramyocellular signaling

\section{REFERENCES}

1. Flegal KM, Kruszon-Moran D, Carroll MD, Fryar CD. Ogden CL Trends in obesity among adults in the united states, 2005 to 2014. JAMA. (2016) 315:2284-91. doi: 10.1001/jama.2016.6458 cascades (Table 2). Identification of mechanisms responsible for greater basal anabolic signaling molecule phosphorylation could potentially yield novel therapeutic targets.

Obesity is an inherently variable condition, which likely explains the observations discussed throughout this review. For example, insulin resistance can manifest itself as impaired fasting glucose, glucose intolerance, or both (145). In fact, the variability in glucose metabolic outcomes with obesity has been extensively discussed $(102,145)$. With this in mind, differences in insulin sensitivity or inflammation may impact muscle protein synthetic responses and explain some of the variability observed in the various studies discussed in this review.

The studies of acute resistance exercise discussed above employed robust exercise protocols in excess of most recommendations for untrained weightlifters (146-148). It is remarkable that this exercise prescription was insufficient to augment myofibrillar protein synthesis rates after protein ingestion. There is potential that increasing the exercise volume could have a positive impact on postprandial myofibrillar protein synthesis rates; similar to improvements seen in older anabolic resistant adults (149). Future studies should focus on long-term interventions that include combined diet and exercise strategies to reduce obesity and examine the impact of weight loss and/or exercise training status on postprandial muscle protein synthesis and anabolic signaling. These longterm studies could also benefit from the use of deuterium oxide (heavy water) to determine free-living rates of muscle protein synthesis during an intervention period. However, differences between nutritional interventions (e.g., protein type, leucine dose) on acute rates of myofibrillar protein synthesis in response to a single meal ingestion with traditional primed constant infusions may be less pronounced when assessed by $\mathrm{D} 2 \mathrm{O}$ in a free-living environment $(150,151)$, highlighting the need for additional research utilizing a variety of stable isotope methodologies to study the presence and consequence of obesity-related anabolic resistance. Dietary interventions should focus on ensuring adequate protein nutrition $(\sim 1.2$ $\mathrm{g} / \mathrm{kg} /$ day). Ideally, future studies would incorporate more comprehensive metabolic profiling (e.g., measures of insulin sensitivity) that would allow better insight as to how the phenomena of metabolic (ab)normality with obesity (102) affects muscle protein synthesis responses to dietary protein and exercise.

\section{AUTHOR CONTRIBUTIONS}

JB wrote the first draft of the manuscript. NB, DM, and SV critically revised the text and made substantial contributions to the manuscript. All authors approved the final version of the manuscript.

2. Hales CM, Carroll MD, Fryar CD, Ogden CL. Prevalence of obesity among adults and youth: United States, 2015-2016. NCHS Data Brief. (2017) 1-8.

3. Wang YC, McPherson K, Marsh T, Gortmaker SL, Brown M. Health and economic burden of the projected obesity trends in the USA and the UK. Lancet Lond. Engl. (2011) 378:815-25. doi: 10.1016/S0140-6736(11)60814-3 
4. Gallagher EJ, LeRoith D. Obesity and diabetes: the increased risk of cancer and cancer-related mortality. Physiol. Rev. (2015) 95:727-48. doi: 10.1152 /physrev.00030.2014

5. Pi-Sunyer X. The medical risks of obesity. Postgrad. Med. (2009) 121:21-33. doi: 10.3810/pgm.2009.11.2074

6. Aune D, Sen A, Prasad M, Norat T, Janszky I, Tonstad S, et al. BMI and all cause mortality: systematic review and non-linear dose-response metaanalysis of 230 cohort studies with 3.74 million deaths among 30.3 million participants. BMJ. (2016) 353:i2156. doi: 10.1136/bmj.i2156

7. Cawley J, Meyerhoefer C. The medical care costs of obesity: an instrumental variables approach. J. Health Econ. (2012) 31:219-30. doi: $10.1016 /$ j.jhealeco.2011.10.003

8. Kushner RF. Weight loss strategies for treatment of obesity. Prog. Cardiovasc. Dis. (2014) 56:465-72. doi: 10.1016/j.pcad.2013.09.005

9. Gallagher D, Kelley DE, Thornton J, Boxt L, Pi-Sunyer X, Lipkin E, et al. Changes in skeletal muscle and organ size after a weight-loss intervention in overweight and obese type 2 diabetic patients. Am J Clin Nutr. (2017) 105:78-84. doi: 10.3945/ajcn.116.139188

10. Hector AJ, Marcotte GR, Churchward-Venne TA, Murphy $\mathrm{CH}$, Breen L, Allmen M. et al. Whey protein supplementation preserves postprandial myofibrillar protein synthesis during short-term energy restriction in overweight and obese adults. J Nutr. (2015) 145:246-52. doi: 10.3945/jn.114.200832

11. Clamp LD, Hume DJ, Lambert EV, Kroff J. Successful and unsuccessful weight-loss maintainers: strategies to counteract metabolic compensation following weight loss. J Nutr Sci. (2018) 7:e20. doi: 10.1017/jns.20 18.11

12. Wolfe RR. The underappreciated role of muscle in health and disease. Am J Clin Nutr. (2006) 84:475-82. doi: 10.1093/ajcn/84.3.475

13. Astrup A. Macronutrient balances and obesity: the role of diet and physical activity. Public Health Nutr. (1999) 2:341-7. doi: $10.1017 /$ S1368980099000464

14. Baron AD, Brechtel G, Wallace P, Edelman SV. Rates and tissue sites of non-insulin- and insulin-mediated glucose uptake in humans. Am J Physiol. (1988) 255:E769-74. doi: 10.1152/ajpendo.1988.255.6. E769

15. Bickerton AST, Roberts R, Fielding BA, Hodson L, Blaak EE, Wagenmakers AJM, et al. Preferential uptake of dietary fatty acids in adipose tissue and muscle in the postprandial period. Diabetes. (2007) 56:168-76. doi: $10.2337 / \mathrm{db} 06-0822$

16. Groen BBL, Horstman AM, Hamer HM, de Haan M, van Kranenburg J, Bierau J, et al. Post-prandial protein handling: you are what you just ate. PLoS ONE. (2015) 10:141582. doi: 10.1371/journal.pone.0141582

17. Fouillet H, Gaudichon C, Mariotti F, Bos C, Huneau JF, Tomé D. Energy nutrients modulate the splanchnic sequestration of dietary nitrogen in humans: a compartmental analysis. Am J Physiol Endocrinol Metab. (2001) 281, E248-60. doi: 10.1152/ajpendo.2001.281.2.E248

18. Jacome-Sosa M, Parks EJ, Bruno RS, Tasali E, Lewis GF, Schneeman BO, et al. Postprandial metabolism of macronutrients and cardiometabolic risk: recent developments, emerging concepts, and future directions. Adv Nutr Bethesda Md. (2016) 7:364-74. doi: 10.3945/an.115.01 0397

19. DeFronzo RA, Tripathy, D. Skeletal muscle insulin resistance is the primary defect in type 2 diabetes. Diabetes Care. (2009) 32 (Suppl. 2):S157-63. doi: $10.2337 / \mathrm{dc} 09-\mathrm{S} 302$

20. Millward DJ, Garlick PJ, Nnanyelugo DO, Waterlow JC. The relative importance of muscle protein synthesis and breakdown in the regulation of muscle mass. Biochem J. (1976) 156:185-8. doi: 10.1042/bj15 60185

21. Pennings B, Groen B, Gijsen AP, Zorenc AH, Senden JMG, Loon LJC, et al. van Amino acid absorption and subsequent muscle protein accretion following graded intakes of whey protein in elderly men. Am J Physiol Endocrinol Metab. (2012) 302:E992-9. doi: 10.1152/ajpendo.00517.2011

22. Biolo G, Tipton KD, Klein S, Wolfe RR. An abundant supply of amino acids enhances the metabolic effect of exercise on muscle protein. Am J Physiol. (1997) 273:E122-9. doi: 10.1152/ajpendo.1997.273. $1 . \mathrm{E} 122$
23. Jones GM, Mayer RJ. Degradation of glucose-metabolizing enzymes in the rat small intestine during starvation. Biochem J. (1973) 132:657-61. doi: $10.1042 /$ bj1320657a

24. Fritz PJ, Vesell ES, White EL, Pruitt KM. The roles of synthesis and degradation in determining tissue concentrations of lactate dehydrogenase5*. Proc Natl Acad Sci USA. (1969) 62:558-65. doi: 10.1073/pnas.62. 2.558

25. Jaleel A, Henderson GC, Madden BJ, Klaus KA, Morse DM, Gopala S, et al. Identification of de novo synthesized and relatively older proteins. Diabetes. (2010) 59:2366-74. doi: 10.2337/db10-0371

26. Ramamurthy B, Höök P, Jones AD, Larsson L. Changes in myosin structure and function in response to glycation. FASEB J Off Publ Fed Am Soc Exp Biol. (2001) 15:2415-22. doi: 10.1096/fj.01-0183com

27. Watanabe H, Ogasawara M, Suzuki N, Nishizawa N, Ambo K. Glycation of myofibrillar protein in aged rats and mice. Biosci Biotechnol Biochem. (1992) 56:1109-12. doi: 10.1271/bbb.56.1109

28. Odessey R, Khairallah EA, Goldberg AL. Origin and possible significance of alanine production by skeletal muscle. J Biol Chem. (1974) 249:7623-9.

29. Felig P, Marliss E, Pozefsky T, Cahill GF. Amino acid metabolism in the regulation of gluconeogenesis in man. Am J Clin Nutr. (1970) 23:986-92. doi: $10.1093 /$ ajen/23.7.986

30. Bak AM, Møller AB, Vendelbo MH, Nielsen TS, Viggers R, Rungby J, et al. Differential regulation of lipid and protein metabolism in obese vs. lean subjects before and after a 72-h fast. Am J Physiol Endocrinol Metab. (2016) 311:E224-35. doi: 10.1152/ajpendo.00464.2015

31. Hodson N, Philp A. The importance of mTOR trafficking for human skeletal muscle translational control. Exerc Sport Sci Rev. (2019) 47:46-53. doi: 10.1249/JES.0000000000000173

32. Hodson N, McGlory C, Oikawa SY, Jeromson S, Song Z, Ruegg MA, et al. Differential localisation and anabolic responsiveness of mTOR complexes in human skeletal muscle in response to feeding and exercise. Am J Physiol Cell Physiol. (2017) 313:C604-11. doi: 10.1152/ajpcell.00176.2017

33. Abou Sawan S, van Vliet S, Parel JT, Beals JW, Mazzulla M, West DWD, et al. Translocation and protein complex co-localization of mTOR is associated with postprandial myofibrillar protein synthesis at rest and after endurance exercise. Physiol Rep. (2018) 6:13628. doi: 10.14814/phy2.13628

34. Song Z, Moore DR, Hodson N, Ward C, Dent JR, O'Leary MF, et al. Resistance exercise initiates mechanistic target of rapamycin (mTOR) translocation and protein complex co-localisation in human skeletal muscle. Sci Rep. (2017) 7:5028. doi: 10.1038/s41598-017-05483-x

35. Hodson N, Brown T, Joanisse S, Aguirre N, West DWD, Moore DR, et al. Characterisation of L-Type amino acid transporter 1 (LAT1) expression in human skeletal muscle by immunofluorescent microscopy. Nutrients. (2017) 10:23. doi: 10.3390/nu10010023

36. Moro T, Ebert SM, Adams CM, Rasmussen BB. Amino acid sensing in skeletal muscle. Trends Endocrinol Metab. (2016) 27:796-806. doi: $10.1016 /$ j.tem.2016.06.010

37. Kimball SR. Integration of signals generated by nutrients, hormones, and exercise in skeletal muscle. Am J Clin Nutr. (2014) 99:237S-42S. doi: $10.3945 /$ ajcn.113.068387

38. Greenhaff PL, Karagounis LG, Peirce N, Simpson EJ, Hazell M, Layfield R, et al. Disassociation between the effects of amino acids and insulin on signaling, ubiquitin ligases, and protein turnover in human muscle. Am J Physiol Endocrinol Metab. (2008) 295:E595-604. doi: 10.1152/ajpendo.90411.2008

39. Wilkinson SB, Phillips SM, Atherton PJ, Patel R, Yarasheski KE, Tarnopolsky $\mathrm{MA}$, et al. Differential effects of resistance and endurance exercise in the fed state on signalling molecule phosphorylation and protein synthesis in human muscle. J Physiol. (2008) 586:3701-17. doi: 10.1113/jphysiol.2008.153916

40. Beals JW, Skinner SK, McKenna CF, Poozhikunnel EG, Farooqi SA, van Vliet $S$, et al. Altered anabolic signalling and reduced stimulation of myofibrillar protein synthesis after feeding and resistance exercise in people with obesity. J Physiol. (2018) 596:5119-33. doi: 10.1113/JP276210

41. Tran L, Kras KA, Hoffman N, Ravichandran J, Dickinson JM, D’Lugos A, et al. Lower fasted-state but greater increase in muscle protein synthesis in response to elevated plasma amino acids in obesity. Obesity. (2018) 26:1179-87. doi: 10.1002/oby.22213 
42. Beals JW, Sukiennik RA, Nallabelli J, Emmons RS, van Vliet S, Young JR, et al. Anabolic sensitivity of postprandial muscle protein synthesis to the ingestion of a protein-dense food is reduced in overweight and obese young adults. Am J Clin Nutr. (2016) 104:1014-22. doi: 10.3945/ajcn.116.130385

43. McGlory C, White A, Treins C, Drust B, Close GL, Maclaren DPM, et al. Application of the $[\gamma-32 \mathrm{P}]$ ATP kinase assay to study anabolic signaling in human skeletal muscle. J Appl Physiol Bethesda Md. (2014) 116:504-13. doi: 10.1152/japplphysiol.01072.2013

44. Moore DR, Tang JE, Burd NA, Rerecich T, Tarnopolsky MA, Phillips SM. Differential stimulation of myofibrillar and sarcoplasmic protein synthesis with protein ingestion at rest and after resistance exercise. J Physiol. (2009) 587:897-904. doi: 10.1113/jphysiol.2008.164087

45. Moore DR, Atherton PJ, Rennie MJ, Tarnopolsky MA, Phillips SM. Resistance exercise enhances mTOR and MAPK signalling in human muscle over that seen at rest after bolus protein ingestion. Acta Physiol. (2011) 201:365-72. doi: 10.1111/j.1748-1716.2010.02187.x

46. Hyde R, Peyrollier K, Hundal HS. Insulin promotes the cell surface recruitment of the SAT2/ATA2 system A amino acid transporter from an endosomal compartment in skeletal muscle cells. J Biol Chem. (2002) 277:13628-34. doi: 10.1074/jbc.M108609200

47. Yang Y, Breen L, Burd NA, Hector AJ, Churchward-Venne TA, Josse AR, et al. Resistance exercise enhances myofibrillar protein synthesis with graded intakes of whey protein in older men. Br J Nutr. (2012) 108:1780-8. doi: 10.1017/S0007114511007422

48. Moore DR, Churchward-Venne TA, Witard O, Breen L, Burd NA, Tipton $\mathrm{KD}$, et al. Protein ingestion to stimulate myofibrillar protein synthesis requires greater relative protein intakes in healthy older versus younger men. J Gerontol A Biol Sci Med Sci. (2014) 70:57-62. doi: 10.1093/gerona/glu103

49. Moore DR, Robinson MJ, Fry JL, Tang JE, Glover EI, Wilkinson SB, et al. Ingested protein dose response of muscle and albumin protein synthesis after resistance exercise in young men. Am J Clin Nutr. (2009) 89:161-8. doi: 10.3945/ajcn.2008.26401

50. Robinson MJ, Burd NA, Breen L, Rerecich T, Yang Y, Hector AJ, et al. Dosedependent responses of myofibrillar protein synthesis with beef ingestion are enhanced with resistance exercise in middle-aged men. Appl Physiol Nutr Metab. (2012) 38:120-5. doi: 10.1139/apnm-2012-0092

51. Burd NA, Beals JW, Martinez IG, Salvador AF, Skinner SK. Foodfirst approach to enhance the regulation of post-exercise skeletal muscle protein synthesis and remodeling. Sports Med Auckl NZ. (2019) 49:59-68. doi: 10.1007/s40279-018-1009-y

52. Phillips SM, Chevalier S, Leidy HJ. Protein "requirements" beyond the RDA: implications for optimizing health. Appl Physiol Nutr Metab Physiol Appliquée Nutr Métabo. (2016) 41:565-72. doi: 10.1139/apnm-2015-0550

53. Rooyackers OE, Balagopal P, Nair KS. Measurement of synthesis rates of specific muscle proteins using needle biopsy samples. Muscle Nerve Suppl. (1997) 5:S93-96.

54. Burd NA, West DWD, Moore DR, Atherton PJ, Staples AW, Prior T, et al. Enhanced amino acid sensitivity of myofibrillar protein synthesis persists for up to $24 \mathrm{~h}$ after resistance exercise in young men. J Nutr. (2011) 141:568-73. doi: $10.3945 /$ jn. 110.135038

55. Robinson MM, Soop M, Sohn TS, Morse DM, Schimke JM, Klaus $\mathrm{KA}$, et al. High insulin combined with essential amino acids stimulates skeletal muscle mitochondrial protein synthesis while decreasing insulin sensitivity in healthy humans. J Clin Endocrinol Metab. (2014) 99:E2574-83. doi: 10.1210/jc.2014-2736

56. Donges CE, Burd NA, Duffield R, Smith GC, West DWD, Short MJ, et al. Concurrent resistance and aerobic exercise stimulates both myofibrillar and mitochondrial protein synthesis in sedentary middle-aged men. J Appl Physiol. (2012) 112:1992-2001. doi: 10.1152/japplphysiol.00166.2012

57. Rooyackers OE, Adey DB, Ades PA, Nair KS. Effect of age on in vivo rates of mitochondrial protein synthesis in human skeletal muscle. Proc Natl Acad Sci USA. (1996) 93:15364-69. doi: 10.1073/pnas.93.26.15364

58. Guillet C, Delcourt I, Rance M, Giraudet C, Walrand S, Bedu M, et al. Changes in basal and insulin and amino acid response of whole body and skeletal muscle proteins in obese men. J Clin Endocrinol Metab. (2009) 94:3044-50. doi: 10.1210/jc.2008-2216

59. Murton AJ, Marimuthu K, Mallinson JE, Selby AL, Smith K, Rennie MJ, et al. Obesity appears to be associated with altered muscle protein synthetic and breakdown responses to increased nutrient delivery in older men, but not reduced muscle mass or contractile function. Diabetes. (2015) 64:3160-71. doi: $10.2337 / \mathrm{db} 15-0021$

60. Smeuninx B, Mckendry J, Wilson D, Martin U, Breen L. Age-related anabolic resistance of myofibrillar protein synthesis is exacerbated in obese inactive individuals. J Clin Endocrinol Metab. (2017) 102:3535-45. doi: 10.1210/jc.2017-00869

61. Chevalier S, Burgos SA, Morais JA, Gougeon R, Bassil M, Lamarche $\mathrm{M}$, et al. Protein and glucose metabolic responses to hyperinsulinemia, hyperglycemia, and hyperaminoacidemia in obese men. Obesity. (2015) 23:351-8. doi: 10.1002/oby.20943

62. Beals JW, Mackenzie RWA, van Vliet S, Skinner SK, Pagni BA, Niemiro GM, et al. Protein-rich food ingestion stimulates mitochondrial protein synthesis in sedentary young adults of different BMIs. J Clin Endocrinol Metab. (2017) 102:3415-24. doi: 10.1210/jc.2017-00360

63. Griffin ME, Marcucci MJ, Cline GW, Bell K, Barucci N, Lee D, et al. Free fatty acid-induced insulin resistance is associated with activation of protein kinase C theta and alterations in the insulin signaling cascade. Diabetes. (1999) 48:1270-4. doi: 10.2337/diabetes.48.6.1270

64. Bohé J, Low JFA, Wolfe RR, Rennie MJ. Latency and duration of stimulation of human muscle protein synthesis during continuous infusion of amino acids. J Physiol. (2001) 532:575-9. doi: 10.1111/j.1469-7793.2001.0575f.x

65. van Vliet S, Shy EL, Sawan SA, Beals JW, West DW, Skinner SK, et al. Consumption of whole eggs promotes greater stimulation of postexercise muscle protein synthesis than consumption of isonitrogenous amounts of egg whites in young men. Am J Clin Nutr. (2017) 106:1401-12. doi: 10.3945/ajcn.117.159855

66. Burd NA, Gorissen SH, van Vliet S, Snijders T, Loon LJ. van Differences in postprandial protein handling after beef compared with milk ingestion during postexercise recovery: a randomized controlled trial. Am J Clin Nutr. (2015) 102:828-36. doi: 10.3945/ajcn.114.103184

67. Sukkar MY, Hunter WM, Passmore R. Changes in plasma levels of insulin and growth-hormone levels after a protein meal. Lancet. (1967) 290:1020-2. doi: 10.1016/S0140-6736(67)90291-7

68. Mithieux G. Metabolic effects of portal vein sensing. Diabetes Obes Metab. (2014) 16:56-60. doi: 10.1111/dom.12338

69. de Lartigue G, Diepenbroek C. Novel developments in vagal afferent nutrient sensing and its role in energy homeostasis. Curr Opin Pharmacol. (2016) 31:38-43. doi: 10.1016/j.coph.2016.08.007

70. Lindgren O, Pacini G, Tura A, Holst JJ, Deacon CF, Ahrén B. Incretin effect after oral amino acid ingestion in humans. J Clin Endocrinol Metab. (2015) 100:1172-6. doi: 10.1210/jc.2014-3865

71. Williamson DL, Dungan CM, Mahmoud AM, Mey JT, Blackburn BK, Haus JM. Aberrant REDD1-mTORC1 responses to insulin in skeletal muscle from Type 2 diabetics. Am J Physiol Regul Integr Comp Physiol. (2015) 309:R855-63. doi: 10.1152/ajpregu.00285.2015

72. Hulston CJ, Woods RM, Dewhurst-Trigg R, Parry SA, Gagnon S, Baker L, et al. Resistance exercise stimulates mixed muscle protein synthesis in lean and obese young adults. Physiol Rep. (2018) 6:13799. doi: $10.14814 /$ phy2.13799

73. Root HF, Carpenter TM. Studies of carbohydrate metabolism in cases of insulin resistance. Trans Am Clin Climatol Assoc. (1940) 56:1-11.

74. Lister J, Nash J, Ledingham U. Constitution and insulin sensitivity in diabetes mellitus. Br Med J. (1951) 1:376-9. doi: 10.1136/bmj.1.4703.376

75. Newgard CB, An J, Bain JR, Muehlbauer MJ, Stevens RD, Lien LF, et al. A branched-chain amino acid-related metabolic signature that differentiates obese and lean humans and contributes to insulin resistance. Cell Metab. (2009) 9:311-26. doi: 10.1016/j.cmet.2009.02.002

76. Felig P, Marliss E, Cahill GF. Plasma amino acid levels and insulin secretion in obesity. $N$ Engl J Med. (1969) 281:811-6. doi: 10.1056/NEJM196910092811503

77. Lerin C, Goldfine AB, Boes T, Liu M, Kasif S, Dreyfuss JM, et al. Defects in muscle branched-chain amino acid oxidation contribute to impaired lipid metabolism. Mol Metab. (2016) 5:926-36. doi: 10.1016/j.molmet.2016.08.001

78. Tai ES, Tan MLS, Stevens RD, Low YL, Muehlbauer MJ, Goh DLM, et al. Insulin resistance is associated with a metabolic profile of altered protein metabolism in Chinese and Asian-Indian men. Diabetologia. (2010) 53:75767. doi: $10.1007 / \mathrm{s} 00125-009-1637-8$ 
79. Boulet MM, Chevrier G, Grenier-Larouche T, Pelletier M, Nadeau M, Scarpa J, et al. Alterations of plasma metabolite profiles related to adipose tissue distribution and cardiometabolic risk. Am J Physiol Endocrinol Metab. (2015) 309:E736-46. doi: 10.1152/ajpendo.00231.2015

80. Würtz P, Mäkinen V-P, Soininen P, Kangas AJ, Tukiainen T, Kettunen J, et al. Metabolic signatures of insulin resistance in 7,098 young adults. Diabetes. (2012) 61:1372-80. doi: 10.2337/db11-1355

81. Wang TJ, Larson MG, Vasan RS, Cheng S, Rhee EP, McCabe E, et al. Metabolite profiles and the risk of developing diabetes. Nat Med. (2011) 17:448-53. doi: 10.1038/nm.2307

82. Gannon NP, Schnuck JK, Vaughan RA. BCAA metabolism and insulin sensitivity - dysregulated by metabolic status? Mol Nutr Food Res. (2018) 62:e1700756. doi: 10.1002/mnfr.201700756

83. Lynch CJ, Adams SH. Branched-chain amino acids in metabolic signalling and insulin resistance. Nat Rev Endocrinol. (2014) 10:723-36. doi: $10.1038 /$ nrendo.2014.171

84. Gran P, Larsen AE, Bonham M, Dordevic AL, Rupasinghe T, Silva C, et al. Muscle p70S6K phosphorylation in response to soy and dairy rich meals in middle aged men with metabolic syndrome: a randomised crossover trial. Nutr Metab. (2014) 11:46. doi: 10.1186/1743-7075-11-46

85. Golay A, Swislocki AM, Chen YDI, Jaspan JB, Reaven GM. Effect of obesity on ambient plasma glucose, free fatty acid, insulin, growth hormone, and glucagon concentrations. J Clin Endocrinol Metab. (1986) 63:481-4. doi: $10.1210 /$ jcem-63-2-481

86. Boden G, Jadali F, White J, Liang Y, Mozzoli M, Chen X, Coleman E, Smith, C. Effects of fat on insulin-stimulated carbohydrate metabolism in normal men. J. Clin. Invest. (1991) 88:960-6. doi: 10.1172/JCI115399

87. Stephens FB, Chee C, Wall BT, Murton AJ, Shannon CE, van Loon LJC, et al. Lipid induced insulin resistance is associated with an impaired skeletal muscle protein synthetic response to amino acid ingestion in healthy young men. Diabetes. (2014) 64:1615-20. doi: 10.2337/db14-0961

88. Goodpaster BH, He J, Watkins S, Kelley DE. Skeletal muscle lipid content and insulin resistance: evidence for a paradox in endurance-trained athletes. J Clin Endocrinol Metab. (2001) 86:5755-61. doi: 10.1210/jc.86.12.5755

89. Daemen S, Gemmink A, Brouwers B, Meex RCR, Huntjens PR, Schaart $\mathrm{G}$, et al. Distinct lipid droplet characteristics and distribution unmask the apparent contradiction of the athlete's paradox. Mol Metab. (2018) 17:71-81. doi: 10.1016/j.molmet.2018.08.004

90. Lee JS, Pinnamaneni SK, Eo SJ, Cho IH, Pyo JH, Kim CK, et al. Saturated, but not n-6 polyunsaturated, fatty acids induce insulin resistance: role of intramuscular accumulation of lipid metabolites. J Appl Physiol. (2006) 100:1467-74. doi: 10.1152/japplphysiol.01438.2005

91. Perreault L, Newsom SA, Strauss A, Kerege A, Kahn DE, Harrison KA, et al. Intracellular localization of diacylglycerols and sphingolipids influences insulin sensitivity and mitochondrial function in human skeletal muscle. JCI Insight. (2018) 3:96805. doi: 10.1172/jci.insight.96805

92. Hla T, Kolesnick R. C16:0-ceramide signals insulin resistance. Cell Metab. (2014) 20:703-5. doi: 10.1016/j.cmet.2014.10.017

93. Bergman BC, Brozinick JT, Strauss A, Bacon S, Kerege A, Bui HH, et al. Muscle sphingolipids during rest and exercise: a C18:0 signature for insulin resistance in humans. Diabetologia. (2016) 59:785-98. doi: 10.1007/s00125-015-3850-y

94. Hyde R, Hajduch E, Powell DJ, Taylor PM, Hundal HS. Ceramide downregulates System a amino acid transport and protein synthesis in rat skeletal muscle cells. FASEB J. (2004) 19:461-3. doi: 10.1096/fj.04-2284fje

95. Timmerman KL, Lee JL, Dreyer HC, Dhanani S, Glynn EL, Fry CS, et al. Insulin stimulates human skeletal muscle protein synthesis via an indirect mechanism involving endothelial-dependent vasodilation and mammalian target of rapamycin complex 1 signaling. J Clin Endocrinol Metab. (2010) 95:3848-57. doi: 10.1210/jc.2009-2696

96. Timmerman KL, Dhanani S, Glynn EL, Fry CS, Drummond MJ, Jennings K, et al. A moderate acute increase in physical activity enhances nutritive flow and the muscle protein anabolic response to mixed nutrient intake in older adults. Am J Clin Nutr. (2012) 95:1403-12. doi: 10.3945/ajcn.111.020800

97. Moore DR, Kelly RP, Devries MC, Churchward-Venne TA, Phillips SM, Parise G, et al. Low-load resistance exercise during inactivity is associated with greater fibre area and satellite cell expression in older skeletal muscle. $J$ Cachexia Sarcopenia Muscle. (2018) 9:747-54. doi: 10.1002/jcsm.12306
98. Devries MC, Breen L, Von Allmen M, MacDonald MJ, Moore DR, Offord $\mathrm{EA}$, et al. Low-load resistance training during step-reduction attenuates declines in muscle mass and strength and enhances anabolic sensitivity in older men. Physiol Rep. (2015) 3:12493. doi: 10.14814/phy2.12493

99. Snijders T, Nederveen JP, Verdijk LB, Houben AJHM, Goossens GH, Parise G, et al. Muscle fiber capillarization as determining factor on indices of insulin sensitivity in humans. Physiol Rep. (2017) 5:13278. doi: 10.14814 /phy2.13278

100. Gavin TP, Stallings HW, Zwetsloot KA, Westerkamp LM, Ryan NA, Moore RA, et al. Lower capillary density but no difference in VEGF expression in obese vs. lean young skeletal muscle in humans. J Appl Physiol Bethesda Md 1985. (2005) 98:315-21. doi: 10.1152/japplphysiol.00353.2004

101. Clerk LH, Vincent MA, Jahn LA, Liu Z, Lindner JR, Barrett EJ. Obesity blunts insulin-mediated microvascular recruitment in human forearm muscle. Diabetes. (2006) 55:1436-42. doi: 10.2337/db05-1373

102. Samocha-Bonet D, Dixit VD, Kahn CR, Leibel RL, Lin X, Nieuwdorp M, et al. Metabolically healthy and unhealthy obese - the 2013 Stock Conference report. Obes Rev Off J Int Assoc Study Obes. (2014) 15:697-708. doi: 10.1111/obr.12199

103. Kitahara CM, Trabert B, Katki HA, Chaturvedi AK, Kemp TJ, Pinto LA, et al. Body mass index, physical activity, and serum markers of inflammation, immunity, and insulin resistance. Cancer Epidemiol Biomarkers Prev. (2014) 23:2840-9. doi: 10.1158/1055-9965.EPI-14-0699-T

104. Dali-Youcef N, Mecili M, Ricci R, Andrès E. Metabolic inflammation: connecting obesity and insulin resistance. Ann Med. (2013) 45:242-53. doi: 10.3109/07853890.2012.705015

105. Volpe CMO, Nogueira-Machado JA. The dual role of free fatty acid signaling in inflammation and therapeutics. Recent Pat Endocr Metab Immune Drug Discov. (2013) 7:189-97. doi: 10.2174/187153031131399 90041

106. Guillet C, Masgrau A, Walrand S, Boirie Y. Impaired protein metabolism: interlinks between obesity, insulin resistance and inflammation. Obes Rev. (2012) 13:51-7. doi: 10.1111/j.1467-789X.2012.01037.x

107. Porter C, Hurren NM, Herndon DN, Børsheim E. Whole body and skeletal muscle protein turnover in recovery from burns. Int J Burns Trauma. (2013) 3:9-17.

108. van Vliet S, Skinner SK, Beals JW, Pagni BA, Fang H-Y, Ulanov AV, et al. Dysregulated handling of dietary protein and muscle protein synthesis after mixed-meal ingestion in maintenance hemodialysis patients. Kidney Int Rep. (2018) 3:1403-15. doi: 10.1016/j.ekir.2018.08.001

109. Wåhlin-Larsson B, Wilkinson DJ, Strandberg E, Hosford-Donovan A, Atherton PJ, Kadi F. Mechanistic links underlying the impact of c-reactive protein on muscle mass in elderly. Cell Physiol Biochem Int J Exp Cell Physiol Biochem Pharmacol. (2017) 44:267-78. doi: 10.1159/000484679

110. Lang CH, Frost RA, Nairn AC, MacLean DA, Vary TC. TNF-alpha impairs heart and skeletal muscle protein synthesis by altering translation initiation. Am J Physiol Endocrinol Metab. (2002) 282:E336-47. doi: 10.1152/ajpendo.00366.2001

111. Buffière C, Mariotti F, Savary-Auzeloux I, Migné C, Meunier N, Hercberg $\mathrm{S}$, et al. Slight chronic elevation of C-reactive protein is associated with lower aerobic fitness but does not impair meal-induced stimulation of muscle protein metabolism in healthy old men. J Physiol. (2015) 593:1259-72. doi: 10.1113/jphysiol.2014.286054

112. Dideriksen K, Reitelseder S, Malmgaard-Clausen NM, Bechshoeft R, Petersen RK, Mikkelsen UR, et al. No effect of anti-inflammatory medication on postprandial and postexercise muscle protein synthesis in elderly men with slightly elevated systemic inflammation. Exp Gerontol. (2016) 83:120-9. doi: 10.1016/j.exger.2016.07.016

113. Chow JC, Young DW, Golenbock DT, Christ WJ, Gusovsky F. Toll-like receptor-4 mediates lipopolysaccharide-induced signal transduction. J Biol Chem. (1999) 274:10689-92. doi: 10.1074/jbc.274.16.10689

114. Shi H, Kokoeva MV, Inouye K, Tzameli I, Yin H, Flier JS. TLR4 links innate immunity and fatty acid-induced insulin resistance. J Clin Invest. (2006) 116:3015-25. doi: 10.1172/JCI28898

115. Liu N, Liu J-T, Ji Y-Y, Lu P-P. C-reactive protein triggers inflammatory responses partly via TLR4/IRF3/NF- $\mathrm{B}$ signaling pathway in rat vascular smooth muscle cells. Life Sci. (2010) 87:367-74. doi: 10.1016/j.lfs.2010.0 7.012 
116. Kwon OS, Tanner RE, Barrows KM, Runtsch M, Symons JD, Jalili T, et al. MyD88 regulates physical inactivity-induced skeletal muscle inflammation, ceramide biosynthesis signaling, and glucose intolerance. Am J Physiol Endocrinol Metab. (2015) 309:E11-21. doi: 10.1152/ajpendo.00124.2015

117. Timmerman KL, Connors ID, Deal MA, Mott RE. Skeletal muscle TLR4 and TACE are associated with body fat percentage in older adults. Appl Physiol Nutr Metab. (2016) 41:446-51. doi: 10.1139/apnm-2015-0567

118. Ekelund U, Steene-Johannessen J, Brown WJ, Fagerland MW, Owen N, Powell KE, Bauman A, et al. Does physical activity attenuate, or even eliminate, the detrimental association of sitting time with mortality? A harmonised meta-analysis of data from more than 1 million men and women. Lancet. (2016) 388:1302-10. doi: 10.1016/S0140-6736(16)30370-1

119. Kanagasabai T, Thakkar NA, Kuk JL, Churilla JR, Ardern CI. Differences in physical activity domains, guideline adherence, and weight history between metabolically healthy and metabolically abnormal obese adults: a cross-sectional study. Int J Behav Nutr Phys Act. (2015) 12:227. doi: 10.1186/s12966-015-0227-z

120. Stenholm S, Harris TB, Rantanen T, Visser M, Kritchevsky SB, Ferrucci, L. Sarcopenic obesity - definition, etiology and consequences. Curr Opin Clin Nutr Metab Care. (2008) 11:693-700. doi: 10.1097/MCO.0b013e328312c37d

121. Koopman R, Manders RJF, Zorenc AHG, Hul GBJ, Kuipers H, Keizer HA, et al. A single session of resistance exercise enhances insulin sensitivity for at least $24 \mathrm{~h}$ in healthy men. Eur J Appl Physiol. (2005) 94:180-7. doi: 10.1007/s00421-004-1307-y

122. Whyte LJ, Ferguson C, Wilson J, Scott RA, Gill JMR. Effects of single bout of very high-intensity exercise on metabolic health biomarkers in overweight/obese sedentary men. Metabolism. (2013) 62:212-9. doi: 10.1016/j.metabol.2012.07.019

123. Short KR, Vittone JL, Bigelow ML, Proctor DN, Rizza RA, Coenen-Schimke $\mathrm{JM}$, et al. Impact of aerobic exercise training on age-related changes in insulin sensitivity and muscle oxidative capacity. Diabetes. (2003) 52:188896. doi: 10.2337/diabetes.52.8.1888

124. Ashor AW, Lara J, Siervo M, Celis-Morales C, Oggioni C, Jakovljevic DG, et al. Exercise modalities and endothelial function: a systematic review and dose-response meta-analysis of randomized controlled trials. Sports Med Auckl NZ. (2015) 45:279-96. doi: 10.1007/s40279-014-0272-9

125. Paris HL, Foright RM, Werth KA, Larson LC, Beals JW, Cox-York K, et al. Increasing energy flux to decrease the biological drive toward weight regain after weight loss - A proof-of-concept pilot study. Clin Nutr ESPEN. (2015) 11:e12-20. doi: 10.1016/j.clnesp.2015.11.005

126. Manore MM, Larson-Meyer DE, Lindsay AR, Hongu N, Houtkooper L. Dynamic energy balance: an integrated framework for discussing diet and physical activity in obesity prevention-is it more than eating less and exercising more? Nutrients. (2017) 9:9080905. doi: 10.3390/nu9080905

127. Wilburn JR, Bourquin J, Wysong A, Melby CL. Resistance exercise attenuates high-fructose, high-fat-induced postprandial lipemia. Nutr Metab Insights. (2015) 8:29-35. doi: 10.4137/NMI.S32106

128. Pennings B, Koopman R, Beelen M, Senden JM, Saris WH, van Loon LJ. Exercising before protein intake allows for greater use of dietary proteinderived amino acids for de novo muscle protein synthesis in both young and elderly men. Am J Clin Nutr. (2011) 93:322-31. doi: 10.3945/ajcn.2010.29649

129. Phillips SM, Tipton KD, Ferrando AA, Wolfe RR. Resistance training reduces the acute exercise-induced increase in muscle protein turnover. Am J Physiol Endocrinol Metab. (1999) 276:E118-24. doi: 10.1152/ajpendo.1999.276.1.E118

130. Jaleel A, Short KR, Asmann YW, Klaus KA, Morse DM, Ford GC, Nair $\mathrm{KS}$. In vivo measurement of synthesis rate of individual skeletal muscle mitochondrial proteins. Am J Physiol Endocrinol Metab. (2008) 295:E125568. doi: 10.1152/ajpendo.90586.2008

131. Mittendorfer B, Andersen J, Plomgaard P, Saltin B, Babraj J, Smith K, et al. Protein synthesis rates in human muscles: neither anatomical location nor fibre-type composition are major determinants. J Physiol. (2005) 563:203-11. doi: 10.1113/jphysiol.2004.077180

132. You J-S, Lincoln HC, Kim C-R, Frey JW, Goodman CA, Zhong X$\mathrm{P}$, et al. The role of diacylglycerol kinase $\zeta$ and phosphatidic acid in the mechanical activation of mammalian target of rapamycin (mTOR) signaling and skeletal muscle hypertrophy. J Biol Chem. (2014) 289:1551-63. doi: 10.1074/jbc.M113.531392
133. Hornberger TA, Chu WK, Mak YW, Hsiung JW, Huang SA, Chien S. The role of phospholipase $\mathrm{D}$ and phosphatidic acid in the mechanical activation of mTOR signaling in skeletal muscle. Proc Natl Acad Sci U S A. (2006) 103:4741-6. doi: 10.1073/pnas.0600678103

134. Jacobs BL, You J-S, Frey JW, Goodman CA, Gundermann DM, Hornberger TA. Eccentric contractions increase the phosphorylation of tuberous sclerosis complex-2 (TSC2) and alter the targeting of TSC2 and the mechanistic target of rapamycin to the lysosome. J Physiol. (2013) 591:461120. doi: 10.1113/jphysiol.2013.256339

135. Abou Sawan S, van Vliet S, West DWD, Beals JW, Paluska SA, Burd NA, et al. Whole egg, but not egg white, ingestion induces mTOR colocalization with the lysosome after resistance exercise. Am J Physiol Cell Physiol. (2018) 315:C537-43. doi: 10.1152/ajpcell.00225.2018

136. Mebarek S, Komati H, Naro F, Zeiller C, Alvisi M, Lagarde M, et al. Inhibition of de novo ceramide synthesis upregulates phospholipase D and enhances myogenic differentiation. J Cell Sci. (2007) 120:407-16. doi: $10.1242 /$ jcs. 03331

137. Sanal E, Ardic F, Kirac S. Effects of aerobic or combined aerobic resistance exercise on body composition in overweight and obese adults: gender differences. a randomized intervention study. Eur J Phys Rehabil Med. (2013) 49:1-11.

138. Smiles WJ, Churchward-Venne TA, van Loon LJC, Hawley JA, Camera DM. A single bout of strenuous exercise overcomes lipid-induced anabolic resistance to protein ingestion in overweight, middle-aged men. FASEB J Off Publ Fed Am Soc Exp Biol. (2019). doi: 10.1096/fj.201801917R. [Epub ahead of print].

139. Smith GI, Villareal DT, Sinacore DR, Shah K, Mittendorfer B. Muscle protein synthesis response to exercise training in obese, older men and women. Med Sci Sports Exerc. (2012) 44:1259-66. doi: 10.1249/MSS.0b013e3182496a41

140. Villareal DT, Smith GI, Sinacore DR, Shah K, Mittendorfer B. Regular multicomponent exercise increases physical fitness and muscle protein anabolism in frail, obese, older adults. Obesity. (2011) 19:312-8. doi: 10.1038/oby.2010.110

141. Villareal DT, Smith GI, Shah K, Mittendorfer B. Effect of weight loss on the rate of muscle protein synthesis during fasted and fed conditions in obese older adults. Obes Silver Spring Md. (2012) 20:1780-6. doi: 10.1038/oby.2011.280

142. Pasiakos SM, Cao JJ, Margolis LM, Sauter ER, Whigham LD, McClung JP, et al. Effects of high-protein diets on fat-free mass and muscle protein synthesis following weight loss: a randomized controlled trial. FASEB J Off Publ Fed Am Soc Exp Biol. (2013) 27:3837-47. doi: 10.1096/fj.13-230227

143. Hector AJ, McGlory C, Damas F, Mazara N, Baker SK, Phillips SM. Pronounced energy restriction with elevated protein intake results in no change in proteolysis and reductions in skeletal muscle protein synthesis that are mitigated by resistance exercise. FASEB J Off Publ Fed Am SocExp Biol. (2018) 32:265-75. doi: 10.1096/fj.201700158RR

144. Leidy HJ, Clifton PM, Astrup A, Wycherley TP, Westerterp-Plantenga MS, Luscombe-Marsh ND, et al. The role of protein in weight loss and maintenance. Am J Clin Nutr. (2015) 101:1320S-9S. doi: 10.3945/ajcn.114.084038

145. Perreault L, Bergman BC, Playdon MC, Dalla Man C, Cobelli C, Eckel $\mathrm{RH}$. Impaired fasting glucose with or without impaired glucose tolerance: progressive or parallel states of prediabetes? Am J Physiol Endocrinol Metab. (2008) 295:E428-35. doi: 10.1152/ajpendo.90354.2008

146. American College of Sports Medicine. American college of sports medicine position stand. progression models in resistance training for healthy adults. Med Sci Sports Exerc. (2009) 41:687-708. doi: 10.1249/MSS.0b013e3181915670

147. CSEP. Canadian Society for Exercise Physiology - Home. Available online at: http://csep.ca/home (accessed March 14, 2018).

148. Donnelly JE, Blair SN, Jakicic JM, Manore MM, Rankin JW, Smith BK, American college of sports medicine american college of sports medicine position stand. appropriate physical activity intervention strategies for weight loss and prevention of weight regain for adults. Med Sci Sports Exerc. (2009) 41:459-71. doi: 10.1249/MSS.0b013e3181949333

149. Kumar V, Atherton PJ, Selby A, Rankin D, Williams J, Smith K, et al. Muscle protein synthetic responses to exercise: effects of age, volume, and intensity. J Gerontol Ser A. (2012) 67:1170-7. doi: 10.1093/gerona/gls141 
150. Devries MC, McGlory C, Bolster DR, Kamil A, Rahn M, Harkness $\mathrm{L}$, et al. Leucine, not total protein, content of a supplement is the primary determinant of muscle protein anabolic responses in healthy older women. J Nutr. (2018) 148:1088-95. doi: 10.1093/jn/nx y091

151. Devries MC, McGlory C, Bolster DR, Kamil A, Rahn M, Harkness $\mathrm{L}$, et al. Protein leucine content is a determinant of shorter- and longer-term muscle protein synthetic responses at rest and following resistance exercise in healthy older women: a randomized, controlled trial. Am J Clin Nutr. (2018) 107:217-26. doi: 10.1093/ajcn/nq $\mathrm{x} 028$
Conflict of Interest Statement: The authors declare that the research was conducted in the absence of any commercial or financial relationships that could be construed as a potential conflict of interest.

Copyright (C) 2019 Beals, Burd, Moore and van Vliet. This is an open-access article distributed under the terms of the Creative Commons Attribution License (CC BY). The use, distribution or reproduction in other forums is permitted, provided the original author(s) and the copyright owner(s) are credited and that the original publication in this journal is cited, in accordance with accepted academic practice. No use, distribution or reproduction is permitted which does not comply with these terms. 